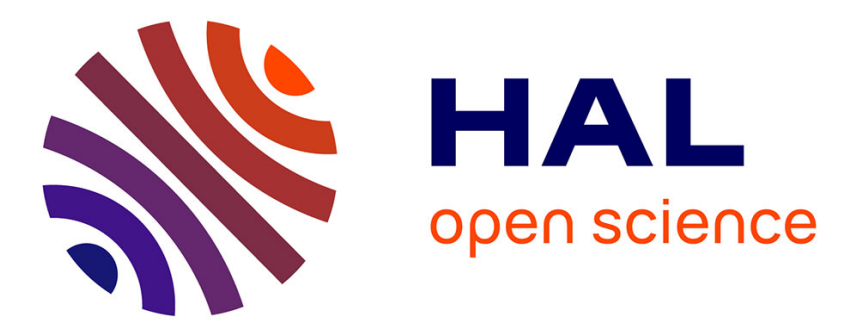

\title{
Biogeochemical characteristics of organic matter in the particulate and colloidal fractions downstream of the rio Negro and Solimoes rivers confluence
}

François Gadel, Léon Serve, Marc Benedetti, Leticia Cotrim da Cunha, Jean-Louis Blazi

\section{To cite this version:}

François Gadel, Léon Serve, Marc Benedetti, Leticia Cotrim da Cunha, Jean-Louis Blazi. Biogeochemical characteristics of organic matter in the particulate and colloidal fractions downstream of the rio Negro and Solimoes rivers confluence. Agronomie, 2000, 20 (5), pp.477-490. 10.1051/agro:2000143 . hal-00886064

\section{HAL Id: hal-00886064 https://hal.science/hal-00886064}

Submitted on 1 Jan 2000

HAL is a multi-disciplinary open access archive for the deposit and dissemination of scientific research documents, whether they are published or not. The documents may come from teaching and research institutions in France or abroad, or from public or private research centers.
L'archive ouverte pluridisciplinaire HAL, est destinée au dépôt et à la diffusion de documents scientifiques de niveau recherche, publiés ou non, émanant des établissements d'enseignement et de recherche français ou étrangers, des laboratoires publics ou privés. 


\title{
Biogeochemical characteristics of organic matter in the particulate and colloidal fractions downstream of the rio Negro and Solimões rivers confluence
}

\author{
François GAdeL ${ }^{\mathrm{a}}$, Léon Serve ${ }^{\mathrm{b} *}$, Marc Benedetti ${ }^{\mathrm{c}}$, Leticia Cotrim Da CunHA ${ }^{\mathrm{b}}$, \\ Jean-Louis BLAZI ${ }^{\mathrm{a}, \mathrm{b}}$

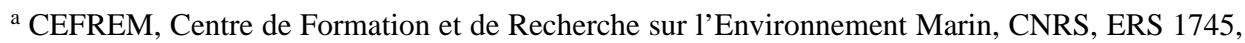 \\ Université de Perpignan, 52 avenue de Villeneuve, 66860 Perpignan Cedex, France \\ ${ }^{\mathrm{b}}$ Laboratoire de Biologie Physico-Chimique, Université de Perpignan, \\ 52 avenue de Villeneuve, 66860 Perpignan Cedex, France \\ c UPRESA CNRS 7047, Laboratoire de Géochimie et Métallogénie, UPMC Case 124, \\ 4 place Jussieu, 75252 Paris Cedex 05, France
}

(Received 4 October 1999; revised 29 February 2000; accepted 18 May 2000)

\begin{abstract}
The analysis of organic matter in the rio Negro, rio Solimões and rio Amazonas focused on total organic carbon (TOC), as determined at two main sizes, the particulate form $(>0.2 \mu \mathrm{m})$ and the colloidal form $(0.2 \mu \mathrm{m}$ to $5000 \mathrm{dal}-$ ton). These fractions were obtained by tangential ultrafiltration carried out on $50 \mathrm{l}$ water samples. The total polysaccharide contents were determined by a colorimetric method, the main classes of organic compounds by pyrolysis and gas chromatography coupled with mass spectrometry (Py-GC-MS), and the lignin or non-lignin phenols by cupric oxide alkaline oxidation and high performance liquid chromatography (HPLC) with photodiode array spectrophotometer detection. Upstream of the confluence of the rio Negro and rio Solimões, the rivers show characteristic differences. The rio Negro has low discharge, high levels of TOC\% for the two fractions, high levels of polysaccharides, low levels of lignin phenols and high levels of hydroxybenzyl non-lignin phenols. The main classes of organic compounds also give a distribution different for the particulate (phenols associated to aromatic compounds) and the colloidal (aromatic compounds and sugars). For the rio Solimões, the compositional features are generally reversed. Downstream of the confluence, the colloidal fraction showed noteworthy levels of lignin-derived compounds associated with increasing levels of polysaccharides correlated to the distance from the confluence.
\end{abstract}

\section{biogeochemistry / organic matter / Py-GC-MS / HPLC / phenols / lignin / particulate / colloidal}

Résumé - Caractères biogéochimiques de la matière organique particulaire et colloïdale en aval de la confluence des rios Negro et Solimões. L'analyse de la matière organique dans les eaux du rio Negro, du rio Solimões et du rio Amazonas a porté sur la charge totale en suspension (TSM) ainsi que sur les fractions particulaire $(>0.2 \mu \mathrm{m})$ et colloïdale $(0.2 \mu \mathrm{m}$ à 5000 dalton). Ces fractions ont été obtenues par ultrafiltration tangentielle exécutée sur des échantillons

Communicated by Isabelle Lamy

* Correspondence and reprints

serve ${ }^{\circledR}$ univ-perp.fr 
de 501 d'eau. Les analyses sont basées sur le dosage du carbone organique total (TOC). Les polysaccharides totaux ont été déterminés par colorimétrie, les classes principales de composés organiques par pyrolyse et chromatographie gazliquide couplée à la spectrométrie de masse (Py-CG-SM) et les phénols, principalement ceux de la lignine, par oxydation alcaline à l'oxyde cuivrique et chromatographie liquide à haute performance (CLHP) avec détection par spectrophotométrie à réseau de diodes. En amont du confluent du rio Negro et du rio Solimões, le fleuve présente des différences caractéristiques. Le rio Negro se distingue par une faible charge solide, par de hauts niveaux de TOC \% pour les deux fractions particulaire et colloïdale, par des niveaux élevés de polysaccharides et par de bas niveaux de phénols de la lignine et de hauts niveaux de phénols hydroxybenzyles non attribuables à la lignine. Les classes principales de composés organiques présentent aussi une distribution différente pour la fraction particulaire (phénols associés aux composés aromatiques) et pour la fraction colloïdale (sucres et composés aromatiques). Pour le rio Solimões, les caractéristiques sont généralement inversées. Enfin, en aval du confluent, la fraction colloidale présente des niveaux remarquables de composés dérivés des lignines associés à des teneurs en polysaccharides croissantes avec la distance au point de confluence.

\section{biogéochimie / matière organique / Py-GC-MS-HPLC / phénols / lignine / particulaire / collö̈dal}

\section{Introduction}

On account of the importance of their fresh water discharge to the oceans $[2,7,9]$ the great tropical floodplain rivers, including the Amazonas, have been subject to many investigations by geochemists, hydrologysts, geologists, chemists and biologists [11, 27, 31]. Organic matter, essentially in its particulate form, and later in its colloidal and dissolved forms, has been studied by many scientists $[7,8,27]$ because of its role in both the origin and end-product of life.

The drainage basin of the Amazonas is of great interest in the study of the global carbon cycle, because of its geographical extent (nearly $6 \times 10^{6} \mathrm{~km}^{2}$ ) and the various origins of the transported load. This is especially true of the dark waters of the rio Negro and the clear waters of the rio Solimões and Madeira basins [22, 23, 26]. The geological nature of the drained terrains is associated with the climatological features in these areas (tropical rainfall distribution through the year and temperatures) and has led to observed differences in qualitative and quantitative determinations of organic compounds in the suspended particulate and colloidal materials, for instance the increase of acid versus aldehyde forms and a correlative increase of vanillic acid/vanillin and syringic acid/syringaldehyde ratios $[10,19,22,25,32,33]$. In the rio Negro basin, soils present extensively podzol profiles developed on acidic and sandy substrates which lead to dark organic matter accumulation in $\mathrm{B}_{\mathrm{h}}$ horizons leached into the rivers. This black, slightly degraded organic matter is known as being reactive, highly polymerized and of both aromatic and acidic nature, presenting great capacities to adsorb onto clayey minerals. On the other hand, the organic matter carried down by the rio Solimões originates from a brown rainforest soil-type and coming into the river waters is associated with minerals into the clayey-humic complex.

The goal of this research is fundamental knowledge of the behaviour of organic matter from different origins in one of the most important riverine systems in the world in terms of carbon input to the oceans. The knowledge of nature, form and yields of organic matter in riverine systems is important for understanding the fate of organic compounds and their accumulation in the ocean. The aim of this work is to characterize the particulate and colloidal fractions of the organic matter transported by the rios Negro (black waters) and Solimões (white waters) upstream and downstream of the point where, after mixing progressively their waters, they become the rio Amazonas.

\section{Materials and methods}

\subsection{Samples}

Water samples were taken during the HiBAm cruise "Campanha Encontro das águas '97", organized by ORSTOM-CNPQ\ANEELIUnB in September 1997. Data of discharge and TSM have 
Table I. General hydrological characteristics of the samples in the course of the mainstream in the studied area (-*: data not available).

\begin{tabular}{rcccc}
\hline $\begin{array}{c}\text { Sampling } \\
\text { site }\end{array}$ & Situation & \multicolumn{2}{c}{ sampling depth (m) } & $\begin{array}{c}\text { Distance to } \\
\text { left bank }(\mathrm{m})\end{array}$ \\
\hline 1 & Rio Negro & 0 & - & $-*$ \\
2 & Rio Solimoes & 0 & - & $-*$ \\
12 & Rio Amazonas & - & -35 & 1156 \\
3 & & 0 & - & $-*$ \\
4 & & 0 & -15 & 650 \\
6 & & 0 & -6 & 1051 \\
\hline
\end{tabular}

been provided by the ORSTOM - CNPQ. Samples (distributed according to the latitude) were collected by Benedetti and Allard along the course of the rio Negro, rio Solimões and downstream in the rio Amazonas where the black and white waters mix. According to Table I and Figure 1, the stations 1 and 2 are situated upstream of the city of Manaus, respectively on the rio Negro and the rio Solimões, and the samples were taken at $0 \mathrm{~m}$ depth. They constitute the sources of organic matter before the water mixing. The stations 12, 3, 4 and 6 are situated on the rio Amazonas, downstram of the city of Manaus and the samples were taken respectively at $-35 \mathrm{~m}, 0 \mathrm{~m}, 0 \mathrm{~m}$ and $-15 \mathrm{~m}, 0 \mathrm{~m}$ and $-6 \mathrm{~m}$ depth.

\subsection{Analytical methods}

Separation of molecular weight fractions was performed from 50 litres of sampled water, imme-

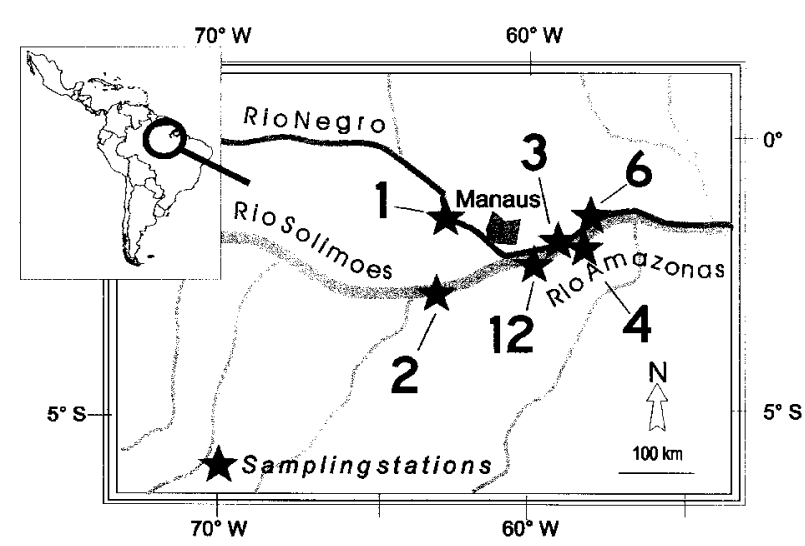

Figure 1. Geographical sketch and situation of the sampled sites in the Amazonas basin. diately ultrafiltered on the vessel, and all fractions preserved in a freezer until their sending to the laboratory by airmail in a refrigerator.

The tangential Ultrafiltration Sartorius apparatus, equipped with regenerated cellulose acetate membrane (cut-off $0.2 \mu \mathrm{m}$ ) and polysulfone membrane (cut-off 5000 dalton), gave two fractions: a fraction $>0.2 \mu \mathrm{m}$ (particulate fraction (C1)) and a fraction ranging between $0.2 \mu \mathrm{m}$ and 5000 dalton (colloidal fraction (C2)).

Organic Carbon content was determined on a freeze-dried aliquot in an automatic LECO 125 CS analyser by dry combustion after decarbonatation by diluted $(2 \mathrm{~N}) \mathrm{H}_{3} \mathrm{PO}_{4}$ and $(2 \mathrm{~N}) \mathrm{HCl}$, and complete drying of the sample.

The main classes of organic compounds were determined by Pyrolysis - Gas Chromatography coupled to Mass Spectrometry (Py-GC-MS). Pyrolysis was carried out at $700{ }^{\circ} \mathrm{C} / 10 \mathrm{~s}$, with a CDS 1000 pyrolysis probe. Gas chromatography used a Perkin-Elmer 8700 fitted with a fused-silica capillary TR-WAX (30 m, $0.32 \mathrm{~mm}$ diameter, $0.25 \mu \mathrm{m}$ phase thickness) column. The gradient started from $60{ }^{\circ} \mathrm{C}$ to $240{ }^{\circ} \mathrm{C}$ with $6{ }^{\circ} \mathrm{C}$ per min rate. The mass spectrometer coupled was a HP 5989.

Twenty three major peaks were selected on the pyrochromatograms and each selected compound was expressed as a percentage of the sum of the area of these 23 peaks [1]. Pyrolysis products were grouped into five main families, each of them including similar molecules or close chemical structures: aromatic hydrocarbons, nitrogenous compounds, sugars, phenols and amino sugars [12].

Polysaccharides were determined colorimetrically. The method involved an oxidation by sulphuric acid $3 \mathrm{~N}$ and then coloration by the anthrone reagent. The samples were left for 20 minutes at $80{ }^{\circ} \mathrm{C}$ into an oven in total darkness. Total polysaccharide concentration was determined using a Spectronic Genesys 5 spectrophotometer at $625 \mathrm{~nm}$ [13].

Phenols were determined by HPLC after cupric oxide alkaline oxidation $(\mathrm{CuO}-\mathrm{NaOH} 2 \mathrm{~N})$ at $170{ }^{\circ} \mathrm{C}$ for 4 hours under $\mathrm{N}_{2}$ in a PTFE bottle enclosed in a stainless steel bomb, followed by an 


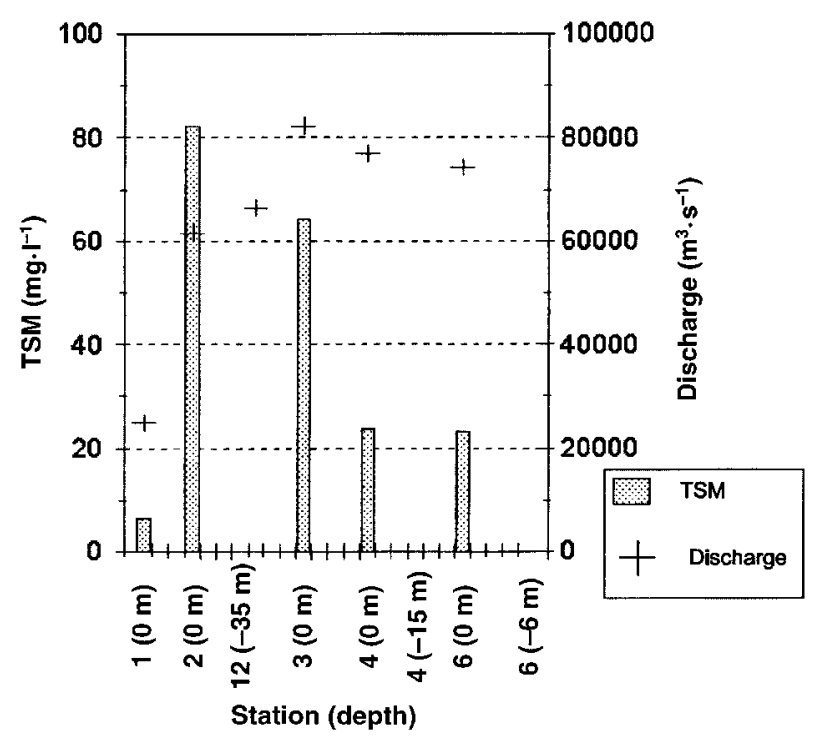

Figure 2. Discharge $\left(\mathrm{m}^{3} \cdot \mathrm{s}^{-1}\right)$ and total suspended matter TSM $\left(\mathrm{mg} \cdot \mathrm{l}^{-1}\right)$ histogram.

ethyl acetate extraction of the acidified solution $(\mathrm{pH} 2)$. Eleven compounds of the lignin $[16,18]$ associated with simple phenols such as typical Hydroxybenzyl compounds are recovered. Phenolic compounds were determined by high performance liquid chromatography (HPLC) [15, 28]. The limit of detection was $10^{-4} \mathrm{~g}$ and the precision of the method was $2 \%$ for each compound [5, 29]. Of a total of 28 identified products, eleven represent the monomers constitutive of lignin and are taken into account according to [17].

The by-products of this oxydative hydrolysis of lignin belong to the following four series: 4-hydro-xybenzyl " $H$ " (p-hydroxybenzoic acid, p-hydroxybenzaldehyde, p-hydroxyacetophenon), 3-methoxy- 4-hydroxybenzylic"V"(Vanillyl) and 3.5-methoxy-4-hydroxybenzylic "S" (Syringyl). Each one of these three series presents an alkyl side chain with 1, 2 or 3 atoms of carbon. The compounds in C6-(C1) can be acids or aldehydes, those in $\mathrm{C6}-(\mathrm{C} 2)$ are ketones and those in $\mathrm{C6}-\mathrm{C} 3$ are acids. In the fourth group, the compounds have a phenylpropenic structure and belong to the Cinnamyl " $\mathrm{C}$ " series (ferulic acid, p-coumaric acid), after [29].

Phenol separation was carried out on a Merck analytical column $(250 \mathrm{~mm}$ long $\times 4 \mathrm{~mm}$ diame- ter). The stationary phase consists of Lichrosorb reversed phase $(\mathrm{C} 1) 8$ of $5 \mu \mathrm{m}$ granulometry, equipped with a precolumn (40 $\mathrm{mm}$ long) containing the same phase. Elution was done using a ternary eluent (water, acetonitrile, acetic acid), according to a high pressure binary gradient defined in reference [5]. The eluted products were identified using a photodiode array spectrophotometer (Shimadzu SPD-M10 Avp, LC-6A chromatographic system), detection being done in UV at $275 \mathrm{~nm}$, even after a co-injection if necessary. The internal standards phloroglucinol (1,3,5-benzenetriol) and p-anisic acid (p-methoxybenzoic acid) allowed the identified products to be determined quantitatively.

\section{Results and discussion}

\subsection{Discharge (Q) and Total Suspended Matter (TSM)}

The recorded discharge was consistent with the general observation recorded by previous authors [15], that the discharge of the rio Amazonas results from the addition of the waters of the rio Negro and those of the rio Solimões. The histograms: $\mathrm{Q}\left(\mathrm{m}^{3} \cdot \mathrm{s}^{-1}\right)$ - TSM $\left(\mathrm{mg} \cdot \mathrm{l}^{-1}\right)$ show the opposing differences of the two stations at rio Negro and rio Solimões (Fig. 2). This observation is consistent with the data recorded by several studies and is related to the analyses of various water constituents such as TOC [25].

At station 1, both TSM and discharge are low. However at station 2, on the rio Solimões, both the discharge and TSM is stronger. At station 3, the values of TSM are lower $\left(65 \mathrm{mg} \cdot \mathrm{l}^{-1}\right)$ than those of station $2\left(80 \mathrm{mg} \cdot 1^{-1}\right)$, while at stations 4 and 6 , the values hardly exceed $20 \mathrm{mg} \cdot \mathrm{l}^{-1}$. River discharge was higher after station 12 , thus the decrease of TSM observed at stations 3, 4 and 6 could be interpreted as a consequence of the settlement of suspended particles in this river section, probably provoked by a slight decrease in the discharge.

\subsection{Total organic carbon: TOC\%}

There are significant differences in the TOC contents between stations 1 and 2 (Tab. II). For 
Table II. Analytical data for C1 (Particulate fraction) and C2 (Colloidal fraction) organic matter fractions. Global analysis: TOC\% (Total particulate organic carbon); Polysaccharides: \%C.Poly. (Percentage of Carbon of Polysaccharides); \%C.Poly./TOC (Ratio of Carbon of Polysaccharides to Total particulate organic carbon); Phenols: Total Phenols (\%TOC) (Sum of Phenols expressed as a percentage of Total particulate organic carbon); (V+S+C) (\%TOC) (Sum of lignin-derived phenolic compounds, V: vanillyl, S: syringyl and C: cinnamyl series expressed as a percentage of Total particulate organic carbon); H (\% TOC) (Lignin or non-lignin derived phenolic compounds, $\mathrm{H}$ : hydroxybenzyl series expressed as a percentage of Total particulate organic carbon); Pyrolysis: AH (rel.\%) (Aromatic hydrocarbons, expressed as a relative percentage of the sum of pyrolysis fragments); Ncomp (rel.\%) (Nitrogenous compounds, expressed as a percentage of Total particulate organic carbon); Sugars (rel.\%) (Sugars, expressed as a percentage of Total particulate organic carbon); Phenols (rel.\%) (Phenols, expressed as a percentage of Total particulate organic carbon); AmSugars (rel.\%) (Amino-sugars, expressed as a percentage of Total particulate organic carbon); ACN/Pyrrol (Ratio of acetonitrile to pyrrol); Benzene/Toluene (Ratio of benzene to toluene); (Furf. + ac.ac.)/ Pyrrol (Ratio of the sum of furfural + acetic acid to pyrrol).

\begin{tabular}{|c|c|c|c|c|c|c|c|c|c|}
\hline \multirow[t]{2}{*}{ Compound } & \multirow[t]{2}{*}{ Fraction } & \multicolumn{8}{|c|}{ Station / Depth } \\
\hline & & $\begin{array}{c}1 \\
(0 \mathrm{~m})\end{array}$ & $\begin{array}{l}2 \\
(0 \mathrm{~m})\end{array}$ & $\begin{array}{c}12 \\
(-35 \mathrm{~m})\end{array}$ & $\begin{array}{c}3 \\
(0 \mathrm{~m})\end{array}$ & $\begin{array}{c}4 \\
(0 \mathrm{~m})\end{array}$ & $\begin{array}{c}4 \\
(-15 \mathrm{~m})\end{array}$ & $\begin{array}{c}6 \\
(0 \mathrm{~m})\end{array}$ & $\begin{array}{c}6 \\
(-6 \mathrm{~m})\end{array}$ \\
\hline \multirow[t]{2}{*}{ Тoc $\%$} & $\mathrm{C} 1$ & 26.96 & 1.33 & 1.96 & 9.30 & 3.74 & 2.61 & 3.75 & 3.28 \\
\hline & $\mathrm{C} 2$ & 16.19 & 8.59 & 8.70 & 11.60 & 33.65 & 12.60 & 15.32 & 14.33 \\
\hline \multirow[t]{2}{*}{ \%C.Poly. } & $\mathrm{C} 1$ & 1.18 & 0.04 & 0.05 & 0.28 & 0.11 & 0.22 & 0.12 & 0.16 \\
\hline & $\mathrm{C} 2$ & 0.23 & 0.26 & 0.20 & 0.34 & 0.35 & 0.49 & 0.98 & 0.21 \\
\hline \multirow[t]{2}{*}{ \%C.Poly. / Org.C. } & $\mathrm{C} 1$ & 4.38 & 2.71 & 2.45 & 3.01 & 2.89 & 8.28 & 3.20 & 4.88 \\
\hline & $\mathrm{C} 2$ & 1.42 & 3.03 & 2.34 & 2.90 & 5.80 & 3.76 & 5.09 & 6.20 \\
\hline \multirow[t]{2}{*}{ Total Phenols (\%POC) } & $\mathrm{C} 1$ & 1.16 & 2.09 & 1.12 & 0.08 & 0.91 & 4.90 & 0.90 & 0.32 \\
\hline & $\mathrm{C} 2$ & 0.64 & 1.34 & 0.53 & 0.35 & 0.65 & 0.88 & 0.39 & 1.25 \\
\hline \multirow[t]{2}{*}{$(\mathrm{V}+\mathrm{S}+\mathrm{C})(\% \mathrm{POC})$} & $\mathrm{C} 1$ & 0.21 & 0.86 & 0.51 & 0.00 & 0.40 & 2.34 & 0.49 & 0.07 \\
\hline & $\mathrm{C} 2$ & 0.27 & 0.19 & 0.14 & 0.13 & 0.24 & 0.19 & 0.13 & 0.47 \\
\hline \multirow[t]{2}{*}{$\mathrm{H}(\% \mathrm{POC})$} & $\mathrm{C} 1$ & 0.70 & 1.23 & 0.61 & 0.08 & - & 1.92 & 0.41 & 0.25 \\
\hline & $\mathrm{C} 2$ & 0.28 & 0.73 & 0.21 & 0.07 & - & 0.21 & 0.10 & 0.39 \\
\hline \multirow[t]{2}{*}{ AH (rel.\%) } & $\mathrm{C} 1$ & 28.10 & 52.40 & 24.40 & 25.40 & 26.00 & 34.60 & 27.00 & 29.10 \\
\hline & $\mathrm{C} 2$ & 31.70 & 19.40 & 25.90 & 23.70 & 24.00 & 22.80 & 19.90 & 24.40 \\
\hline \multirow[t]{2}{*}{ NComp(rel.\%) } & $\mathrm{C} 1$ & 39.20 & 37.50 & 58.00 & 50.60 & 49.90 & 40.70 & 45.50 & 46.40 \\
\hline & $\mathrm{C} 2$ & 36.80 & 49.20 & 39.90 & 41.20 & 42.40 & 42.40 & 45.40 & 49.20 \\
\hline \multirow[t]{2}{*}{ Sugars(rel.\%) } & $\mathrm{C} 1$ & 3.70 & 2.30 & 3.90 & 5.30 & 4.90 & 5.00 & 4.20 & 4.80 \\
\hline & $\mathrm{C} 2$ & 10.70 & 6.20 & 6.00 & 5.30 & 6.10 & 5.10 & 5.90 & 4.80 \\
\hline \multirow[t]{2}{*}{ Phenols(rel.\%) } & $\mathrm{C} 1$ & 28.50 & 7.10 & 11.70 & 16.70 & 18.50 & 19.20 & 22.60 & 17.80 \\
\hline & $\mathrm{C} 2$ & 19.40 & 23.40 & 25.90 & 28.70 & 23.00 & 28.90 & 30.70 & 19.80 \\
\hline \multirow[t]{2}{*}{ AmSugars(rel.\%) } & $\mathrm{C} 1$ & 0.60 & 0.80 & 2.00 & 1.80 & 0.70 & 0.80 & 0.60 & 1.80 \\
\hline & $\mathrm{C} 2$ & 1.30 & 1.60 & 2.20 & 1.00 & 4.50 & 0.70 & 1.20 & 1.70 \\
\hline \multirow[t]{2}{*}{ ACN/Pyrrol } & $\mathrm{C} 1$ & 5.47 & 7.06 & 5.78 & 5.31 & 5.29 & 4.13 & 4.73 & 6.06 \\
\hline & $\mathrm{C} 2$ & 1.82 & 5.32 & 2.56 & 5.2 & 4.92 & 5.42 & 4.64 & 4.97 \\
\hline \multirow[t]{2}{*}{ Benzene/Toluene } & $\mathrm{C} 1$ & 1.21 & 10.17 & 2.05 & 1.83 & 2.07 & 2.31 & 1.67 & 2.48 \\
\hline & $\mathrm{C} 2$ & 1.69 & 1.03 & 1.87 & 1.36 & 1.04 & 1.2 & 1.54 & 1.25 \\
\hline \multirow[t]{2}{*}{ (Furf.+ac.ac.)/Pyrrol } & $\mathrm{C} 1$ & 0.29 & 0.2 & 0.19 & 0.26 & 0.38 & 0.2 & 0.18 & 0.18 \\
\hline & $\mathrm{C} 2$ & 0.53 & 0.31 & 0.92 & 0.21 & 0.17 & 0.22 & 0.17 & 0.14 \\
\hline
\end{tabular}

instance, the particulate fraction (C1) TOC content is $26.96 \%$ for the rio Negro, compared with $2.6 \%$ for the Solimões. For the colloidal fraction (C2), the differences are less marked, being respectively
$16.5 \%$ and $9 \%$, but are not correlated to the TOC values of the particulate fraction (C1) (Tab. II and Fig. 3). The exceptionally high TOC values at stations 1 and 3 for the particulate and colloidal 


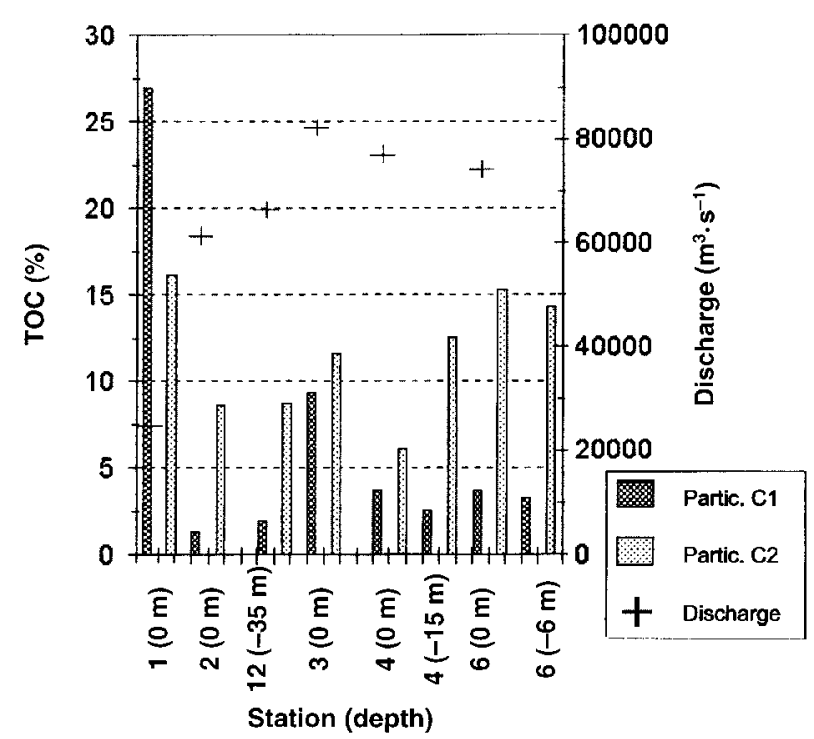

Figure 3. Discharge $\left(\mathrm{m}^{3} \cdot \mathrm{s}^{-1}\right)$ and total particulate organic carbon (TOC) histogram.

fraction indicate a great heterogeneity of water composition. Data at the other stations (12: 1.96\%; $3: 9.3 ; 4: 3.74$ and $2.61 ; 6: 3.75$ and 3.28 ) are consistent with those reported by previous authors $[19,20]$.

The TOC values at the confluence (station 12: $-35 \mathrm{~m}$ ) are similar to those recorded for the rio Solimões (station 2), being respectively $1.96 \%$ and $1.33 \%$. It could perhaps be due to an insufficient mixing of the two river waters since the closer sampling station point was located on the edge-cut mixing line.

At stations 4 and 6, differences appear between the surface sample in station 4 and the 3 other points $(4:-15 \mathrm{~m} ; 6$ : $0 \mathrm{~m}$ and 6 : $-6 \mathrm{~m})$ for the colloidal fraction $(\mathrm{C} 2)$. Particulate fractions $(\mathrm{C} 1)$ present carbon contents which are constant and ranging from 3 to $5 \%$. At these stations, the increase of the colloidal form of carbon could be explained by an additional input of leached colloidal material from the northern tributaries of the rio Amazonas.

Calculated percents of TOC are in accordance with results synthesized by reference [24] and are consistent with those exposed for the rio Amazonas main stem by reference [20].

\subsection{Main classes of organic compounds: (Py-GC-MS)}

\subsubsection{Particulate fraction (C1)}

Stations 1 and 2 are essentially different in their phenol and aromatic hydrocarbon contents (Fig. 4a).

At the confluence (station 12) the relative content in phenols and in aromatic hydrocarbons is more comparable respectively to that of the rio Solimões than to that of the Negro river. The nitrogenous compounds increase strongly in this same station when compared to rios Negro and Solimões: they represent more or less the sum of their respective values. The other stations (3,4 and 6$)$ also have this character, with a slight decrease of the nitrogenous compounds and a corresponding increase of phenols. This decrease of nitrogenous compounds could be put in parallel with the observations of reference [2] of a selective sorption of nitrogenous compounds on minerals in the organic matter of the Amazon basin.

Mainly because of the high lignin contents (20 to $25 \%$ dry weight of woody tissues), aromaticity is a characteristic of organic matter derived from higher-order plant debris and accumulated in the organic horizons of soils. This, however, maybe unfortunately over-estimated by pyrolysis techniques, sugars under high temperature being able to lead to cyclization of their molecule [34]. This character appears with more or less importance in the riverine and lacustrine waters $[1,3]$ which turns the interpretation of results more difficult.

In black waters, such as station 1 on the rio Negro, the run-off of organic matter from the leaching of podzolic soils (i.e. low contents in TSM) of the watershed results in large amounts of phenols and secondary of nitrogenous compounds, characteristic of the raw (weakly degraded) humic material accumulated in the $\mathrm{Bh}$ horizons of podzols. However, the white waters of the rio Solimões are characterized by large amounts of aromatic hydrocarbons with very low contents of phenols. These differences emphasize the contrast in two great regions of Amazonas with their contrasting climatological and pedological environmental conditions. 
a

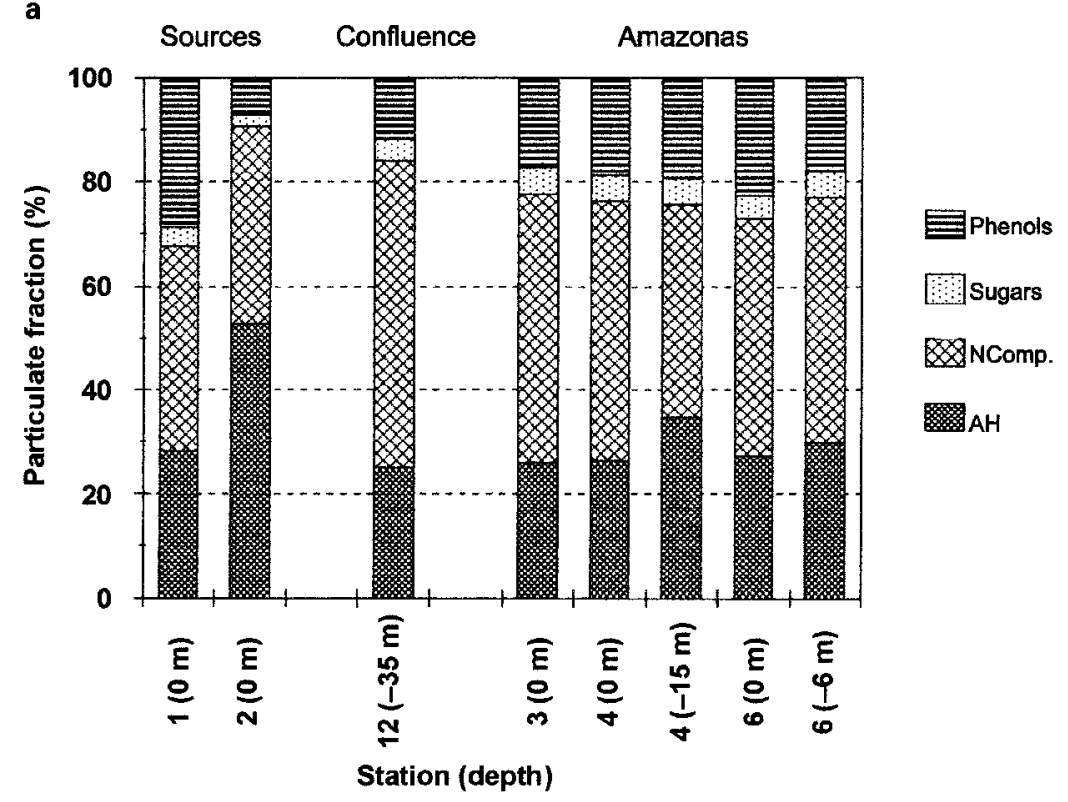

b

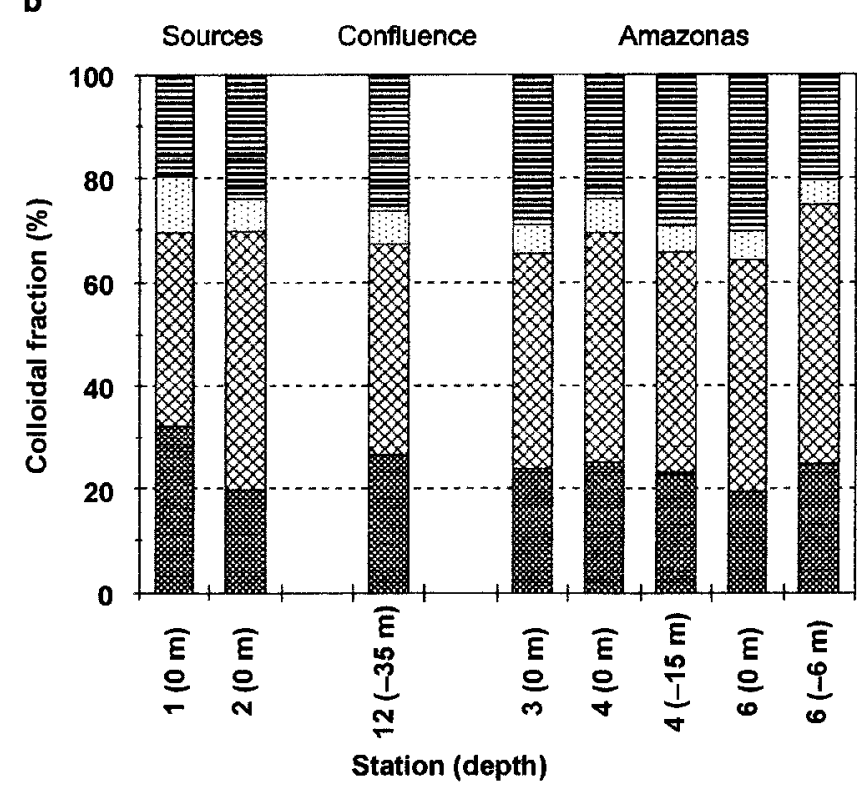

Phenols

Sugars

NComp.

AH

\subsubsection{Colloidal fraction (C2)}

Whereas the compositional patterns of the particulate fraction were quite different from one sourceriver to the other one, the differences disappeared in the colloidal organic matter (Fig. 4b). Within the bulk of organic matter, particulate form is in a fresh state, composed of vegetal debris from forest litters or decayed parts of the organisms, while colloidal form is in a decomposed and/or recomposed state, and consequently is an older organic matter. Nevertheless, at station 1 the highest percentages of aromatic hydrocarbons and sugars can be observed, and could characterize the colloidal fraction of the rio Negro. The colloidal matter from the rio Solimões, with its high TSM contents, is characterized
Figure 4. Distribution of main organic compounds analysed as pyrolysis fragments: AH: aromatic hydrocarbons, Ncomp: nitrogenous compounds, Sugars and Phenols in: (a) particulate (C1) fraction and: (b) colloidal (C2) fraction. 
by high nitrogenous compound contents and low aromatic hydrocarbon contents. This observation illustrates the erosive character of the mineral and organic run-off of the Solimões river compared with that of the Negro river. Podzolic soils are wellknown to be uneroded, the podzolization processes characterized by leaching of colloidal matter from $A_{0}$ to $B_{h}$ accumulation horizons being incompatible with erosion of superficial horizons.

Pyrolysis fragments attributable to the phenols are appreciably more important in the colloidal fraction $(\mathrm{C} 2)$ than in the particulate fraction $(\mathrm{C} 1)$.

The other stations 12, 3, 4 and 6 give results which are quite similar to each other and result from the mixing of the two river waters.

A number of characteristic ratios calculated after references $[1,12]$, slightly modified, can give indications about the trends of transformation of the organic matter. They are generally used to compare organic matter composition to the supposed transformation processes in the course of humification, i.e. fractionation of organic biopolymers and recomposition of new polymers with these same fractions with addition of newly synthesized materials from biological activity of saprophyte organisms.

\section{Acetonitrile/Pyrrole:}

These two nitrogen-containing compounds are at their maximum values in the so-called fresh organic matter compared to aromatic hydrocarbons which predominate in transformed organic matter.

$\mathrm{C} 1$ has higher calculated ratios than (C2), ranging from 4.13 to 7.06 for (C1) (aliphatic nitrogen), and from 1.82 to 5.32 for (C2) (heterocyclic nitrogen). These ratios point out the differences between the two fractions in their capacity to retain nitrogenous compounds.

The high Benzene/Toluene ratio is an indication of a more degraded organic matter. Calculated values range from 1.21 to 10.17 for the particulate fraction (C1), and for the rio Negro, calculated values range between 1.03 to 1.87 for the colloidal fraction $(\mathrm{C} 2)$, corresponding to a less degraded organic matter.
These compounds, benzene and toluene, which could also comprise phenol, have been related to long-term transformation of organic matter, such as a long pedologic transformation where organic matter forms the clayey-humic complex [1]. Furthermore, within colloidal or dissolved carbon in waters, the abundance of polyhydroxyaromatics is an indication of allochthonous organic material [4].

The ratio (Acetic Acid + Furfural)/Pyrrol estimates sugar derivatives versus heterocyclic nitrogen compounds. In this study, it reaches the highest values for colloidal fraction (C2) at station 12 (0.92), which confirms a weakly degraded organic matter in this fraction. The particulate organic matter (C1) contains mainly recently introduced organic debris (values ranging from 0.18 to 0.38 ).

\subsection{Polysaccharides}

The source of polysaccharides in natural environments are mainly the ligno-cellulosic complex, the glucidic polymers accumulated in cytoplasm of vegetal cells (terrestrial as well as aquatic) and the glucidic polymers contained in living organisms in water. In order to consider different kinds of molecules, the carbon of polysaccharides is used in preference to the polysaccharide contents. When compared to the bulk of organic matter, it is better to look at the $\% \mathrm{C}$ of polysaccharide which can be directly compared to TOC $\%$.

\subsubsection{Estimates of \% C. Polysaccharides}

Depending on the station, great differences in total polysaccharide contents between the fractions were observed. For instance, for the particulate fraction $(\mathrm{C} 1)$, higher contents are recorded at station $1(1.18 \%)$ and lower contents at station 2 $(0.04 \%)$. For the colloidal fraction (C2), the contents are similar (0.23 to $0.26 \%)$ for stations 1 and 2 (Fig. 5a).

At the confluence (station 12: $-35 \mathrm{~m})(\mathrm{C} 1)$ and (C2), the values are closely similar to those of station 2.

At the rio Amazonas stations, the polysaccharide values increase until station 6 , at surface. The 
a

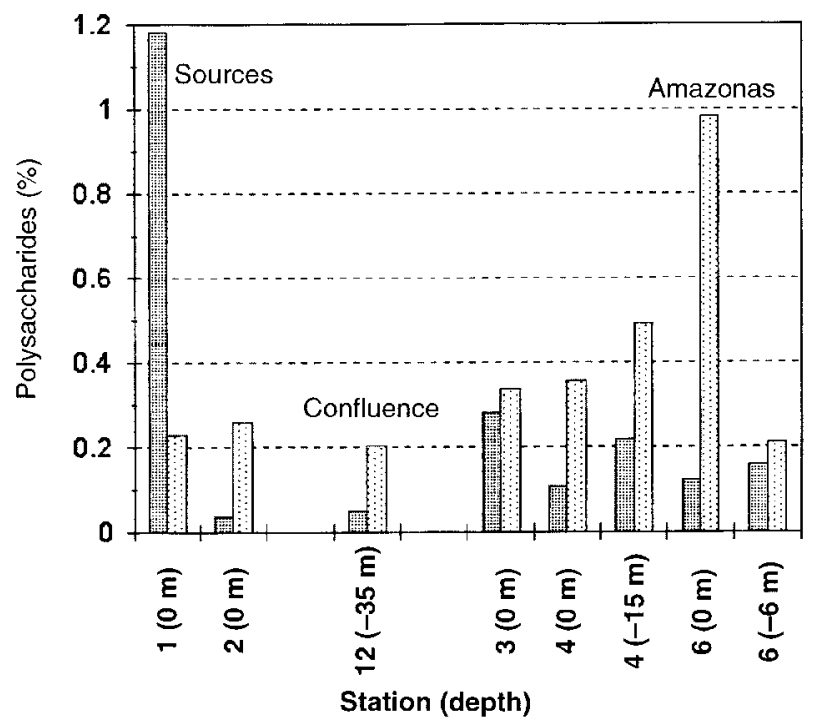

b

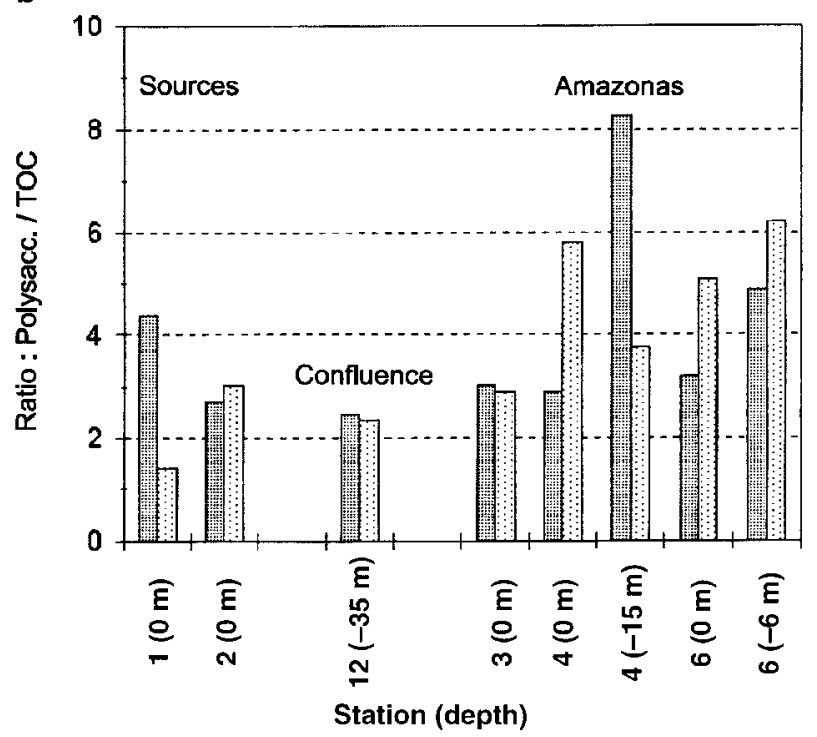

bottom sample at station $6(-6 \mathrm{~m})$, shows higher contents for the colloidal fraction $(\mathrm{C} 2)$.

\subsubsection{Polysaccharides/TOC (\%) ratios}

The differences between stations 1 and 2 are a little less marked than for the C. polysaccharide contents in the particulate fraction (C1) (Fig. 5b).
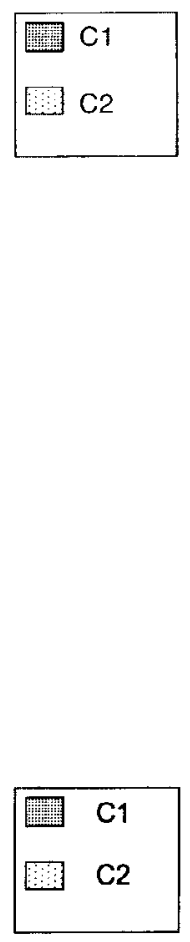

Figure 5. Distribution of Polysaccharides estimated: (a) C. Polysaccharides (\%) and: (b) C. Polysaccharides/TOC ratios.
On the contrary, for the colloidal fraction (C2), an increase of the ratio is observed in station 2 compared to station 1 .

At the confluence (station 12), neither the particulate nor the colloidal fractions give ratios which are similar to those of station 2.

At the stations of rio Amazonas (12, 3, 4 and 6), (C1) and (C2) fractions show an irregularity of values, 


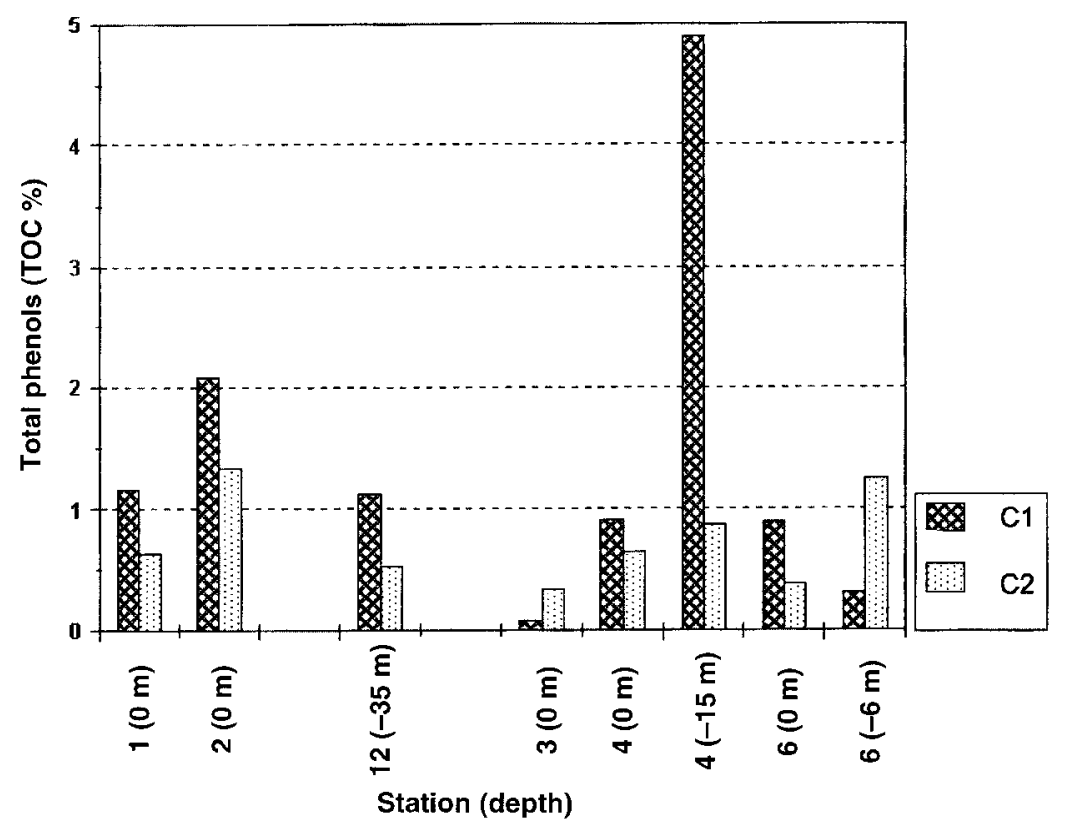

Figure 6. Total phenols (\%TOC) distribution according to particulate (C1) and colloidal (C2) fractions among the sampled sites. with, for the (C2) fraction, a tendency to increase the ratio in station 6 . This increase could be considered as the result of an autochthonous phytoplanktonic activity correlated to the enrichment in TOC from the rio Negro waters.

Polysaccharides are often considered to be microbial-derived metabolites accumulated in soils (allochtonous) or produced directly in waters during seasonal blooms of phytoplancton (autochthonous). Though it is difficult to draw a parallel between polysaccharide contents and monosaccharide yields from other sources [11, 20, 30,33], there could exist a correlation between high polysaccharide contents at station 1 , particulate fraction $(\mathrm{C} 1)$ (biopolymers of plant origin) and the monosaccharide composition of coarse particulate organic matter similar to the composition of tree leaves [20]. The expression of C. Polysaccharides/TOC ratios understate the differences between stations. However, the C. Polysaccharide contents enhance the differences between the river-sources Negro and Solimões, and also indicate an enrichment in polysaccharides of the colloidal fraction (C2) of rio Amazonas, especially at station 6.

\subsection{Phenols}

The method of oxidation of the ligneous material allowed the determination of 11 monomeric compounds constitutive of lignins (according to Hedges and Ertel [11]): acids, aldehydes and ketones of the Vanillyl (V), Syringyl (S) and p-Hydroxybenzyl (H). Compounds of the p-Hydroxybenzyl series are not exclusive to vascular plant material (they can also occur in algae) whereas the acids of the Cinnamyl (C) series occur in monocots. The bulk of phenols is distributed independently of the TOC (\%) except for stations 1 and 2 (Fig. 6). This emphasizes the heterogeneity of organic matter composition along this section of the mainstem: total phenol contents range from 0.08 to $4.9 \%$ TOC for the particulate $(\mathrm{C} 1)$ fraction and from 0.35 to $1.34 \%$ TOC for the colloidal (C2) fraction. The exceptional value of $4.9 \%$ at the station $4(-15 \mathrm{~m}$ depth) corresponds to a sample also enriched in mineral load.

\subsubsection{Particulate fraction (C1)}

The extracted V, S, C and $\mathrm{H}$ compounds show great variability according to the rates of TOC\% in all sampled sites (Fig. 7). 


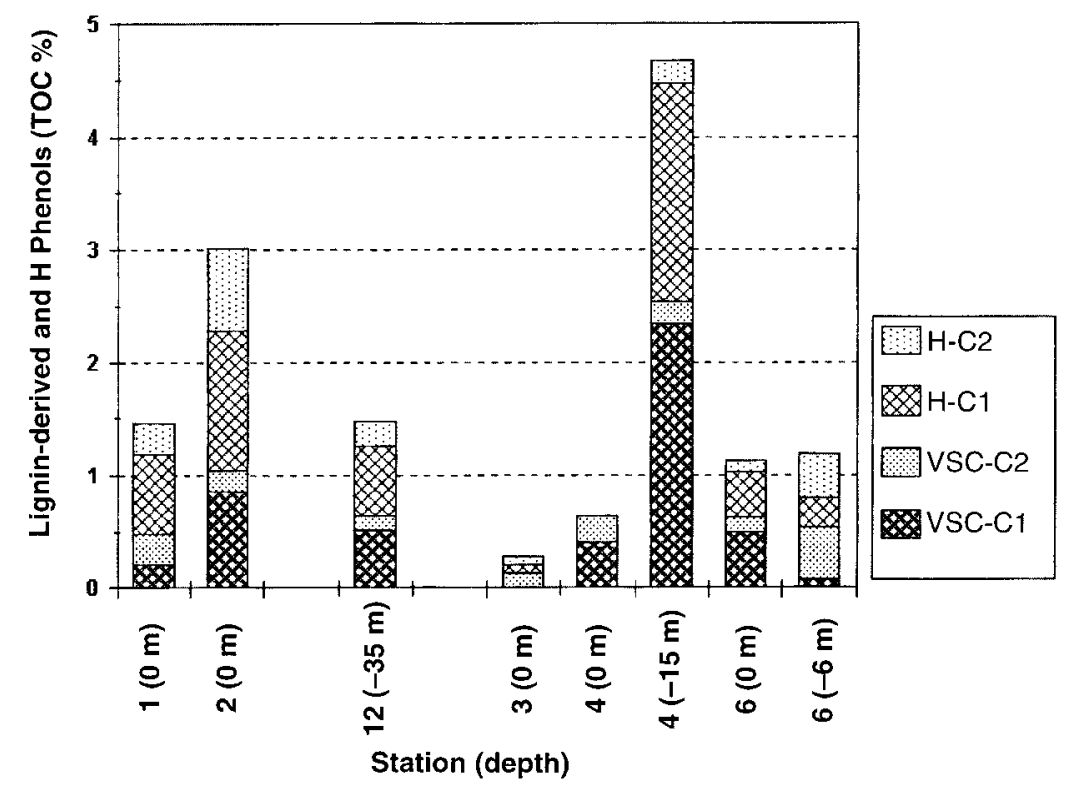

Figure 7. Lignin-derived: $(\mathrm{V}+\mathrm{S}+\mathrm{C})$ and $\mathrm{H}$ phenols (TOC\%) distribution according to particulate $(\mathrm{C} 1)$ and colloidal $(\mathrm{C} 2)$ fractions among the sampled sites.
Depending on the station, differences between the Negro and the Solimões rivers can be observed. The particulate matter or colloidal material of the Negro, very rich in TOC, is yet relatively very poor in lignin as represented by the sum $\mathrm{V}+\mathrm{S}+\mathrm{C}$ (allochthonous) and rich in $\mathrm{H}$ compounds from a native origin. The particulate matter or colloidal material of the rio Solimões, very poor in TOC, is on the other hand very rich in $\mathrm{V}+\mathrm{S}+\mathrm{C}$ (allochthonous) as well as in $\mathrm{H}$ compounds (native origin).

Table III. Raw trends for a schematic conclusion (same abbreviations as for Tab. II).

\begin{tabular}{|c|c|c|c|c|}
\hline & \multicolumn{2}{|c|}{ Rio Negro } & \multicolumn{2}{|c|}{ RioSolimões } \\
\hline Discharge $\left(\mathrm{m}^{3} \cdot \mathrm{s}^{-1}\right)$ & \multicolumn{2}{|c|}{24700} & \multicolumn{2}{|c|}{61300} \\
\hline $\operatorname{TSM}\left(\mathrm{mg} \cdot{ }^{-1}\right)$ & \multicolumn{2}{|c|}{6.4} & \multicolumn{2}{|l|}{60} \\
\hline Organic Matter & $\begin{array}{l}\text { Particulate } \\
\text { fraction } \mathrm{Cl}\end{array}$ & $\begin{array}{l}\text { Colloidal } \\
\text { fraction } \mathrm{C} 2\end{array}$ & $\begin{array}{l}\text { Particulate } \\
\text { fraction } \mathrm{C} 1\end{array}$ & $\begin{array}{l}\text { Colloidal } \\
\text { fraction C2 }\end{array}$ \\
\hline TOC\% & 27 & 16.5 & 3 & 9 \\
\hline Py-GC-MS & Phenols + AH & $\mathrm{AH}+$ Sugars & A & Ncomp \\
\hline Polysaccharides & Higher & Similar & Weak & Similar \\
\hline C.Polysaccharides/ & No significant & & No significant & \\
\hline TOC\% & differences & Weak & differences & High \\
\hline Phenolics & VSC:Weak & VSC: Detected & VSC:High & VS: Detected \\
\hline & H:High & $\begin{array}{l}\text { Small } \\
\text { differences }\end{array}$ & H:High & $\begin{array}{l}\text { Small } \\
\text { differences }\end{array}$ \\
\hline
\end{tabular}

At the confluence, organic matter has a composition in lignin similar to that of the Solimões river. This predominence is probably a result of the high discharge and TSM levels of this river when compared to the same parameters in the Negro river.

At the rio Amazonas stations, great disparities are observed in O.M. lignin contents composition, with the extreme case of stations 3 and 4 , where lignin contents were higher than more than half of the TOC $(\%)$, represented by the lignin compounds $(\mathrm{V}+\mathrm{S}+\mathrm{C})$ associated to high contents of $\mathrm{H}$ compounds which could be in this case from autochthonous origin.

Except for stations $3(0 \mathrm{~m})$ and $4(-15 \mathrm{~m})$, there is a decrease in $\mathrm{H}$ compounds in the particulate fraction which could be compared to the degradation suffered by particulate organic matter on the basis of analyses of carbohydrates [6, 20].

\subsubsection{Colloidal fraction (C2)}

This fraction contains notable proportions of lignin-derived phenolic compounds. The differences previously observed at the stations 1 and 2 are the same, though reduced, in this fraction (Fig. 7). 
On the contrary, at the rio Amazonas stations, except at station $6,(-6 \mathrm{~m}$ depth), the phenol contents are homogenised at lower levels.

This homogeneity of the composition of ligninphenols of colloidal organic matter could correspond to the degradation of lignin components observed in dissolved organic matter by reference [10] and corroborated by analyses of monosaccharides [20].

\section{Conclusion}

The sampling stations, despite their close proximity, showed remarkable differences between the black and white water rivers before their confluence and the variations in the samples analysed after the river mixing were less marked.

The differences between black and white water rivers are qualitative as well as quantitative. The rio Negro samples present high TOC contents, and its particulate organic matter fraction releases phenols and aromatic compounds from a pedologic origin coupled with high concentration of polysaccharides, with low quantities of lignin phenols $(\mathrm{V}+\mathrm{S}+\mathrm{C})$ associated to high levels of $\mathrm{H}$ compounds indicating autochthonous sources. For the Solimões white water river, the situation is reversed.

In the case of the colloidal fraction, the differences are displayed especially in the pyrolysis fragments, like aromatic hydrocarbons and sugars for rio Negro and nitrogenous compounds for rio Solimões, and also the polysaccharide contents, namely the C.Polysaccharide/TOC ratios. TSM values, directly correlated to climatological and geographical features of the watersheds, explain these differences. The erosion of soils and the presence of organo-mineral complexes in the rio Solimões watershed contrasts with raw-humus and the leaching processes of the rio Negro one.

After the confluence, processes affecting organic matter are very difficult to analyse for many reasons, essentially because of the size of natural phenomena, the gigantic values of the dis- charge and the wide/depth of the river flows, and the difficulty to adapt and to realise a suitable sampling strategy.

Despite these difficulties, we are able to suggest some findings about the processes occurring in distribution and state of organic matter in the upper course of rio Amazonas.

The global composition inferred from Py-GCMS analysis shows a great homogeneity at all the stations. The colloidal (C2) fraction would be weakly degraded at all the sites as well as for the rio Negro (C1 and C2).

The polysaccharide contents present increasing values in the colloidal (C2) fraction comparative to the particulate $(\mathrm{C} 1)$ fraction which, on the contrary, decreases according to the distance from the confluence.

Phenols show irregularly distributed values in the (C1) particulate fractions with an exceptionally lignin-derived-compounds enriched sample at the point $4(-15 \mathrm{~m})$. A special feature of the colloidal (C2) fraction at all sites is the presence in noteworthy amounts of $(\mathrm{V}+\mathrm{S}+\mathrm{C})$ lignin-derived compounds, particularly in the two river-sources and at the point $6(-6 \mathrm{~m})$.

Due to the importance of river discharge, it is difficult to evaluate if possible vertical variations in the current velocity are likely to interfere in the homogeneity of the water column and consequently to the sample results.

Acknowledgements: We thank Dr. J.-L. Guyot for communicating general data on the Amazonian environment and discharge data. We are indebted to our colleague L. Comellas, head of the department of Analytical Chemistry at the Institut Quimic de Sarria, Barcelona (Spain) who kindly accepted us in his laboratory and gave us unvaluable indications on the pyrolysis technique. Our thanks are also due to two anonymous reviewers who spent their time in correcting our manuscript.

This research is dedicated to the memory of our old friend and colleague François Gadel whose scientific activity was centered on the study of organic matter. 


\section{References}

[1] Alcañiz J.M., Seres A., Comellas L., Gassiot M., Chemical diversity of pyrograms as a discriminating parameter in soil humus and plant residues, Sci. Total Environ. 68 (1988) 241-249.

[2] Artemyev V.E., Geochemistry of organic matter in river-sea systems, Kluwer Academic Publishers, Dordrecht, 1996, 190 p.

[3] Biber M.V., Gülaçar F.O., Buffle J., Seasonal variations in principal groups of organic matter in an eutrophic lake using Pyrolysis/GC/MS, Environ. Sci. Technol. 30 (1996) 3501-3507.

[4] Bruchet A., Rousseau C., Mallevialle J., PyrolysisGC-MS for investigating high-molecular-weight THM precursors and other refractory organics, J. Am. Water Works Assoc. (1990) 66-74.

[5] Charrière B., Les Composés phénoliques marqueurs de la matière organique terrestre dans deux écosystèmes marins : le Delta du Rhône et le Prodelta de la Têt, Thèse, Institut National Polytechnique de Toulouse, 1991, $182 \mathrm{p}$.

[6] Cowie G.L., Hedges J.I., Biochemical indicators of diagenetic alteration in natural organic matter mixtures, Nature 369 (1994) 304-307.

[7] Cummins K.W., Sedell J.R., Swanson F.J., Minshall G.W., Fisher S.G., Cushing C.E., Petersen R.C., Vannote R.L., Organic budgets for stream ecosystems: problems on their evaluation, in: Barnes J.R., Minshall G.W. (Eds.), Stream Ecology: Application and Testing of General Ecological Theory, Plenum Press, New York, 1983, pp. 299-354.

[8] Degens E.T., Ittekkot V., Particulate organic carbon. An overview, in: Degens E.T, Kempe S., Herrera R. (Eds.), Transport of carbon and minerals in major world rivers, Pt. 3., Mitt. Geol.-Paläont. Inst. Univ. Hamburg, SCOPE/UNEP Sonderb., Vol. 58, 1985, pp. 7-27.

[9] Degens E.T., Riverine carbon. An overview, in: Degens E.T, Kempe S., Herrera R. (Eds.), Transport of carbon and minerals in major world rivers, Pt. 1., Mitt. Geol.-Paläont. Inst. Univ. Hamburg, SCOPE/UNEP Sonderb., Vol. 52, 1982, pp. 1-12.

[10] Ertel J.R., Hedges J.I., Devol A.H., Richey J.E., De Nazaré Goes Ribeiro M., Dissolved humic substances of the Amazonas River system, Limnol. Oceanogr. 31 (1986) 739-754.

[11] Furch K., Water chemistry of the Amazonas basin: The distribution of chemical elements among freshwaters, in: Sioli H. (Ed.), The Amazonas; Limnology and landscape ecology of a mighty tropical river and its basin, W. Junk, Dordrecht, 1984, pp. 167-199.

[12] Gadel F., Bruchet A., Application of pyrolysis gas chromatography-mass spectrometry to the characterization of humic substances resulting from decay of aquatic plants in sediments and waters, Water Res. 21 (1995) 1195-1206.

[13] Gallali T., Étude statique et dynamique des polysaccharides et des aminopolysaccharides au cours de l'humification, Thèse Doct. Univ. Nancy, Nancy, 1972, $93 \mathrm{p}$.

[14] Guyot J.L., Wasson J.G., Regional pattern of riverine dissolved organic carbon in the bolivian Amazonian drainage basin, Limnol. Oceanogr. 39 (1994) 452-458.

[15] Hartley R.D., Buchan H., High performance liquid chromatography of phenolic acids and aldehydes derived from plants or from the decomposition of organic matter in soil, J. Chromatogr. 180 (1979) 139-143.

[16] Hedges J.I., Mann D.C., The characterization of plant tissues by their lignin oxidation products, Geochim. Cosmochim. Acta. 43 (1979) 1809-1818.

[17] Hedges J.I., Ertel J.R., Characterization of lignin by gas capillary chromatography of cupric oxide oxidation products, Anal. Chem. 54 (1982) 174-178.

[18] Hedges J.I., Parker P.L., Land-derived organic matter in surface sediments from the Gulf of Mexico, Geochim. Cosmochim. Acta. 40 (1976) 1019-1029.

[19] Hedges J.I., Clark W.A., Quay P.D., Richey J.E., Devol A.H., Santos U. De M., Compositions and fluxes of particulate organic material in the Amazonas River, Limnol. Oceanogr. 31 (1986) 717-738.

[20] Hedges J.I., Cowie G.L., Richey J.E., Quay P.D., Origins and processing of organic matter in the Amazonas River as indicated by carbohydrates and amino acids, Limnol. Oceanogr. 39 (1994) 743-761.

[21] Ittekkot V., Arain R., Nature of particulate organic matter in the river Indus, Pakistan, Geochim. Cosmochim. Acta 50 (1986) 1643-1653.

[22] Kempe S., Depetris P.J., Factors controlling the concentration of particulate carbohydrates and aminoacids in the Parana river, Hydrobiologia 242 (1992) $175-183$.

[23] Meybeck M., Carbon, Nitrogen and phosphorous transport by world rivers, Am. J. Sci. 282 (1982) 401-450.

[24] Meybeck M., Flux of organic carbon by rivers to the oceans (1981), Workshop Woods Hole, 
Massachusetts, Sept. 21-25, Office of Energy Research, Conf-8009140 U(C1)1, 1980, pp. 219-261.

[25] Patel N., Mounier S., Guyot J.L., Benamou C., Benaïm J.Y., Fluxes of dissolved and colloidal organic carbon along the Purus and Amazonas rivers (Brazil), Sci. Total Environ. 229 (1999) 53-64.

[26] Richey J.E., Victoria R.L., Salati E., Forsberg B.R., The Biogeochemistry of a major river system: the Amazonas case study, in: Degens E.T., Kempe S., Richey J.E. (Eds.), Biogeochemistry of major world rivers, SCOPE (1991), pp. 57-73.

[27] Salati, The climatology and hydrology of Amazonas, in: Prance G.T., Lovejoy T.E. (Eds.), Key Environment Amazonasia, Pergamon Press, Oxford, 1985, pp. 18-48.

[28] Serve L., Piovetti L., Longuemard N., Dosage des acides et aldéhydes phénoliques par chromatographie liquide à haute performance : analyse comparative des sols de haute montagne et de leur végétation, J. Chromatogr. 259 (1983) 319-338.

[29] Serve L., Icole M., Blazi J.-L., Les monomères phénoliques dérivés des lignines dans les sédiments d'une carotte longue du lac du Bouchet (Massif central, France) et la reconstitution des paléoenvironnements, Bull. Soc. géol. Fr. 168 (1997) 507-520.

[30] Sigleo A., Biochemical components in suspended particles and colloïds: carbohydrates in the Potomac and Patuxent estuaries, Org. Geochem. 24 (1996) 83-93.

[31] Sioli H., Amazonas tributaries and drainage basins, Ecol. Stud. 10 (1975) 199-213.

[32] Striquer-Soares F., Chevolot L., Particulate and dissolved carbohydrates and proteins in Lobo Reservoir (Sao Paulo State, Brazil): relationships with phytoplancton, J. Plankt. Res. 18 (1996) 521-537.

[33] Sweet M.S., Perdue E.M., Concentration and speciation of dissolved sugars in river water, Environ. Sci. Technol. 16 (1982) 692-698.

[34] Wilson M.A., Philp R.P., Gillam A.H., Gilbert T.D., Tate K.R., Comparison of the structures of humic substances from aquatic and terrestrial sources by pyrolysis gas-chromatography-mass spectrometry, Geochim. Cosmochim. Acta 47 (1983) 497-502. 